ALPHA Nº 28 Julio 2009 (153-168)

ISSN 0716-4254

http://alpha.ulagos.cl

\title{
LOS TIEMPOS DE LA VIOLENCIA EN CHILE: LA MEMORIA OBSTINADA DE PATRICIO GUZMÁN
}

The times of violence in Chile: The obstinate memory by Patricio Guzmán

Jaume Peris Blanes*

Resumen

Análisis del modo como La memoria obstinada de Patricio Guzmán, trataba de desbloquear la memoria social de la violencia construyendo un documental que hiciera dialogar el discurso de los supervivientes con elementos del archivo y con imágenes del pasado. Se expone cómo, a través de sutiles operaciones discursivas, el documental trata de traer al presente una experiencia de la represión que buena parte de la sociedad trataba de situar en el pasado.

Palabras clave: Memoria, testimonio, duelo, documental, Transición, Chile.

Abstract

The author deals with the place of witness and testimonies in the Guzmán's documentary La memoria obstinada. It places the Guzman's film in the early transition context, where survivors had not the public centrality that they have today. The author analizes how the film tries to bring to the present an experience of repression wich has been set in the past.

Key words: Memory policies, testimony, mourning, documentary, Transition, Chile.

\section{LA INDAGACIÓN EN LA MEMORIA}

En 1996, Patricio Guzmán llevó a Chile una copia de La batalla de Chile su documental rodado en los meses previos al golpe de Estado de 1973 contra el gobierno de Salvador Allende y que mostraba el proceso de organización popular en los días de la Unidad Popular, la respuesta agitada de la burguesía y el desencadenamiento de la violencia que acabó con el proyecto socialista. El film se había convertido, desde el primer momento, en una de las narraciones más importantes a través de las cuales la opinión pública internacional había conocido el proceso chileno y gozó de una impresionante acogida en festivales, ciclos y actos cívicos en buena parte del mundo. En Chile, por el contrario, no se exhibiría hasta 1997, y en unas condiciones de gran precariedad — un único día en una sola sala- lo que 
señalaba el carácter enormemente conflictivo que las imágenes tenían, tanto tiempo después, en el escenario de la Transición chilena.

En 1996, Guzmán tuvo la idea de exhibir su film en diferentes colegios de Santiago y filmar las reacciones de los estudiantes ante un pasado reciente que desconocían. De ese proyecto surgió el documental La memoria obstinada (1996) pero de los cuarenta colegios en los que pidió autorización, solamente cuatro accedieron a su propuesta. Como explicaba el propio cineasta, "sólo me permitieron ir a cuatro colegios. En el resto me dijeron que los chicos se podían traumatizar, que el pasado había que olvidarlo" (Millán, 2001:288).

Al mismo tiempo, el proyecto de La memoria obstinada contemplaba revisitar, 23 años después, buena parte de los espacios filmados en La batalla de Chile para reflexionar sobre la transformación ocurrida en el país durante ese periodo. Se trataba, también, de reencontrar algunos de los rostros que poblaban sus imágenes para explorar, a través de ellos, los recovecos de su memoria traumatizada y la singular inflexión que sus voces adoptaban frente a una escucha atenta que la sociedad de la Transición les había negado. ${ }^{1}$ En el proyecto de la película, elaborado en 1994 por Guzmán, éste explicaba así sus objetivos

Queremos indagar en la memoria, en los recuerdos individuales de la gente. Después del golpe se produjo un honda autocensura en los recuerdos de cientos de miles de personas, que querían y no podían olvidar tantos años de creatividad política, de vida cultural emocionante, cortados luego por una experiencia de dolor y desarraigo (La memoria obstinada. Proyecto, 63).

Así, la intervención de Guzmán trataba de desbloquear una serie de memorias que no habían encontrado espacios de expresión en los años de la Transición, construyendo un dispositivo narrativo muy sutil con el que trataba de conectar la representación de la dictadura y la del espacio social de los años noventa. Para ello, debía elaborar cuidadosamente algunos de los nudos de la memoria que, en la voz de supervivientes, participantes activos de la

${ }^{1}$ La batalla de Chile constituía desde los años setenta un referente incuestionable del cine documental en el exterior de Chile, siendo merecedora de innumerables galardones en festivales de renombre de Estados Unidos, Canadá y Europa. La memoria obstinada, a pesar de sus más modestas dimensiones y del diferente contexto político y cultural en que se exhibió, mereció más de 15 premios en festivales internacionales y fue exhibida en cadenas de televisión públicas de España, Francia o Canadá, con una gran acogida por parte de la crítica especializada y de los emergentes movimientos sociales por la memoria histórica y por la justicia global. 
Los tiempos de la violencia en Chile: La memoria obstinada

movilización popular de los setenta y jóvenes estudiantes que nada conocían del proyecto de la Unidad Popular, hicieran emerger, aunque fuera de forma lateral, algunas de las líneas maestras del proceso histórico que la Transición había intentado borrar.

De hecho, la dinámica de pactos y consensos en que se asentó la construcción de la sociedad transicional estableció una relación de alteridad total entre el régimen democrático y la dictadura militar que le había precedido. Esto es, la tremenda violencia física, económica y simbólica de la dictadura se representó, en los años de la Transición, como un pasado totalmente desvinculado histórica y socialmente de la sociedad de los noventa (Peris Blanes, 2008). El film de Guzmán se situó en unas coordenadas morales muy diferentes y su intervención se planteó, precisamente, como una forma de deshacer esa ilusión de alteridad y de hacer visibles, por medio de un singular trabajo de montaje cinematográfico, la profunda ligazón histórica de la sociedad de los noventa con los tiempos de la dictadura militar. En palabras de Nelly Richard

La memoria obstinada de Patricio Guzmán compromete al recuerdo (la materia sobre cuyas partículas existenciales trabaja la obra) y al espectador (su destinatario) en un mismo proceso de co-producción de sentidos surgido de una interrelacionalidad de planos, temporalidades, escenas, vivencias y subjetividades en acto, que van ensayando posibilidades de relato (1997:57).

\section{LOS SUPERVIVIENTES Y EL TIEMPO DE LA REPRESENTACIÓN}

La llamada "Transición Chilena" ha estado marcada, sin duda, por una larga serie de iniciativas sociales y estatales en el campo de la memoria, que han tratado de dar respuesta, en diferentes ámbitos, a las profundas desgarraduras abiertas por la violencia económica y represiva de la dictadura militar. Sin embargo, y a pesar de la centralidad que los supervivientes han adquirido en las políticas estatales de memoria de los últimos años, en los primeros tiempos de la post-dictadura éstos carecieron no sólo de figuración legal sino, también, de espacios legitimados desde los cuales expresar sus testimonios de la violencia.

De hecho, el Informe de la Comisión Nacional sobre Prisión Política y Tortura, que recogía el testimonio de más de 35.000 supervivientes y —que el gobierno de Lagos hizo público en noviembre del 2004 - trató de colmar una ominosa laguna en las políticas de memoria chilena, que desde la llegada a la democracia habían excluido sistemáticamente a los supervivientes como portadores de historia y como víctimas legítimas del sistema represivo 
dictatorial. A su vez, el Informe de la Comisión Nacional de Verdad y Reparación, que dirigido por Raúl Rettig publicó sus conclusiones en 1991, se había visto limitado a investigar las violaciones de los derechos humanos con resultado de muerte y desaparición, de ese modo, se había negado el estatuto de víctimas a los supervivientes y se habría corrido un tupido velo sobre el carácter masivo e indiscriminado de la represión física y la tortura.

La exclusión de los supervivientes del Informe de la Comisión Nacional de Verdad y Reparación no era más que un efecto de los pactos y negociaciones que habían limitado las políticas de memoria estatales de los primeros años de la Transición. Atrapadas en un sistema de prohibiciones y de fronteras que no se debían traspasar, las políticas de memoria se prodigaron en gestos de contrición y en lamentos colectivos que trasladaban al conjunto de la ciudadanía la responsabilidad de las heridas abiertas por la dictadura. Esa memoria consensual se adhería al lamento de las víctimas y de sus familiares pero, a la vez, evitaba acusar a los responsables de la represión y de la violencia económica. Para que esa ecuación se resolviera sin problemas, era necesario situar el origen del trauma en un espacio simbólico que, aunque cercano en el tiempo, constituyera un pasado tan lejano que su invocación no quebrantara los consensos políticos y sociales en que se estaba cimentando la nueva sociedad. La exclusión de los supervivientes fue, en un primer momento, un elemento imprescindible de esa memoria consensual (Peris Blanes, 2005:195-204).

En otro contexto, pero ya en el ámbito de la teoría y de la práctica cinematográfica, Claude Lanzmann había alertado en la década anterior sobre el proceso de trivialización al que estaba siendo sometido el exterminio de los judíos por los nazis debido, precisamente, a su representación consensuada como un elemento del pasado (1995:202). Por ello, Lanzmann buscaba una forma de hablar del exterminio que trajera a la conciencia del espectador su carácter presente y actual: rechazaba por igual las imágenes de archivo —que congelaban en un tiempo pasado una experiencia que todavía estaba teniendo lugar en la conciencia de los supervivientes- y la ficción reconstructiva, que ofrecía una representación desvirtuadora de la realidad, que era en sí irrepresentable. Si bien esta es una idea discutible, ${ }^{2}$ los textos y la práctica fílmica de Lanzmann apostaban por un tipo de representación cuyo principal

2 La producción teórica de Lanzmann fundamenta en dos cuestiones de principio, que determinan el desarrollo de su pensamiento sobre la representación de los campos, pero creo que no son necesarios compartir para apreciar algunas de sus consideraciones sobre la relación entre ética y representación. Esos dos principios son el carácter intransmisible del horror absoluto y la obscenidad de los intentos de comprensión histórica (Cfr. Peris Blanes. La imposible voz. 2005:62-69). 
objetivo fuera desarticular esa concepción del exterminio como pasado, concepción que, según Lanzmann, nos permitía borrar la presencia del exterminio en nosotros como seres históricos, y la responsabilidad que de ello se derivaba (1979:1897).

No por azar, la apuesta de Lanzmann iba a situar como elemento central a los supervivientes de los campos: en ellos hallaba la actualidad del exterminio, ya que sus cuerpos dolidos y su voz traumatizada hacían de puente entre la experiencia histórica del exterminio y el momento actual en que enunciaban su testimonio. De ese modo, la posición enunciativa del testigo $-\mathrm{y}$ no la ficción reconstructiva o las imágenes de archivo- permitía inscribir el exterminio en el espacio y el tiempo actual, como herida abierta y sangrante de la cual daba cuenta la subjetividad mutilada del testigo. En la obra de Lanzmann, quizás una de las más influyentes de las últimas décadas, sólo el testigo superviviente podía posibilitar el encuentro del tiempo del campo de concentración con el tiempo en que éste era representado.

En el campo cultural de la temprana Transición chilena -y en un momento de redefinición general de los discursos de la memoria- - Guzmán trató de escuchar, en el bullicio del Chile neoliberal, aquellos signos del pasado que, a pesar de todos los intentos por borrarlo, delataban líneas de continuidad entre la violencia de la dictadura y la violencia de la sociedad actual. Y entre las arquitecturas reconstruidas tras los bombardeos, los lugares de memoria y los espacios del terror, Guzmán recurrió también a la palabra de los supervivientes que hacían presente la experiencia de la violencia y atacaban frontalmente la ubicación de ella en un pasado lejano, como había querido la memoria consensual.

Años antes del giro que las políticas estatales de memoria experimentaron con respecto a los supervivientes del que nos hemos ocupado detalladamente en otros trabajos (Peris Blanes, 2008) el film de Guzmán planteaba la necesidad de escuchar la palabra testimonial para hacer emerger una nueva memoria, más allá del ideal consensual. Una memoria que anunciaba, quizás, una nueva representación política que subrayara, y no borrara más, las líneas de continuidad entre el sistema de campos de concentración instaurado tras el golpe del 73 y los modos de exclusión del Chile de la post-dictadura (Kublock, 2003:272).

\section{LA MEMORIA COMO AGENTE NARRATIVO}

En La memoria obstinada se contaba la vuelta a Chile de Patricio Guzmán y de otros exiliados chilenos y el reencuentro con un país absolutamente transformado, que no respondía a las imágenes cristalizadas del recuerdo. Pero, sobre todo, lo que se narraba en la película era la difícil y 
problemática ubicación de otra película en el contexto despolitizado del Chile post-dictatorial: el conflicto de temporalidades y memorias que planteaba la proyección de La batalla de Chile en la escena consensual de la Transición.

Para ello, el film planteaba tres recorridos simultáneos a partir del documental original. En primer lugar, Guzmán trataba de encontrar, veinte años después, a algunos de los ciudadanos filmados en La batalla de Chile, con el fin de darles la oportunidad de relatar el recorrido que, desde entonces, había seguido su vida y, de ese modo, desatascar su memoria subjetiva de la violencia de la dictadura. En segundo lugar, se ponían en escena ciertos acontecimientos vinculados a la Unidad Popular que habían sido representados en La batalla de Chile, pero ahora en el contexto absolutamente diferente del Chile de los noventa. En tercer lugar, y coincidiendo con el final del film, se proyectaba La batalla de Chile en varios colegios de Santiago, organizando un debate entre jóvenes que no habían vivido la época de la Unidad Popular y en el que se hacía explícita la dificultad de inscribir un discurso político de los años setenta en la escena desideologizada del Chile neoliberal.

La película carecía, pues, de una trama unitaria. La unidad del film venía dada, más bien, por una operación discursiva general: cada una de las historias y escenas enfrentaban la diferente textura moral y política de dos momentos históricos muy diferenciados: los años de 1973 y 1996. La figura del testigo que había vivido los acontecimientos de los setenta - y daba cuenta de ellos más de veinte años después - unificaba la aparente disgregación del film: la densidad de su palabra traumatizada suturaba, por una parte, la fragmentación narrativa de la película y, por otra, la aparente discontinuidad entre los dos momentos históricos sobre los que el film volvía una y otra vez.

La película se abría con el testimonio de Juan, antiguo escolta de Allende, acompañado por sus fotografías personales de la época y por las conocidas imágenes televisivas del bombardeo a La Moneda. La diferente textura de esas imágenes en blanco y negro, que contrastaban con el color limpio y cuidado de la imagen de Juan, remitían a diferentes estadios de la tecnología de captación visual y, de ese modo, a momentos históricos diversos. Así, el film proponía un espacio visual en el que coexistían tiempos de enunciación diversos, marcados por la diferente materialidad de sus soportes. Ello se resaltaba aún más cuando las imágenes de archivo del bombardeo se encadenaban a imágenes aéreas en color de La Moneda, tomadas en idéntica posición que las del 73 pero con la tecnología de captación de 1996. Además de esa diferencia tecnológica, el interior del plano mostraba al Palacio de la Moneda perfectamente reconstruido: las huellas de la devastación del golpe militar habían sido perfectamente borradas. 
Mientras una voz nos hablaba en términos muy generales del Golpe y de la Dictadura Militar, se mostraba un desfile de los carabineros en el interior de La Moneda (en 1996), exhibiendo sus cuerpos perfectamente disciplinados y uniformes no demasiado diferentes a aquellos con los que, en los años setenta, se vistieron los actores principales de la represión. La imagen nos mostraba, además, a Juan observando el desfile y simultáneamente la voz over comentaba, refiriéndose a él: "Desde entonces no ha dejado de recordar el combate de la Moneda: era el día de su boda y casi fue el día de su muerte. Ahora, entra al palacio como ayudante de nuestro equipo de filmación, para evocar algunos momentos, e igual que yo, es la primera vez en 23 años que él vuelve a este lugar”.

Este el primer momento en que se hacía referencia a las condiciones y al hecho mismo de la filmación. Además, la voz que sólo había desplegado unas breves generalidades históricas sobre el régimen de Allende y el Golpe Militar comenzaba a ser asignable a un sujeto de la experiencia, atravesado también por el desgaste de la violencia. La emergencia del yo del discurso básico hacía mucho más compleja la escena enunciativa, ya que al vincular la voz a la figura pública del director, ${ }^{3}$ ésta dejaba de ser meramente informativa - como el espectador podía haber creído hasta entonces- y revelaba su dependencia de un sujeto de la experiencia marcado, desde su primera emergencia, por los estragos de la temporalidad.

El film realizaba, en este sentido, una operación bien peculiar, que se repetiría con diferentes matices a lo largo de todo el metraje: se centraba en la historia de Juan y de los diversos testigos que aparecían en la narración y exploraba sus imágenes pasadas y presentes, pero, en ningún momento se aludía directamente a la historia de Patricio Guzmán ni del resto del equipo, ni sus rostros eran convocados por las imágenes. Sobre esa contradicción tomaba cuerpo el relato: aunque el yo enunciativo aludiera lateralmente a una experiencia propia de la violencia y del paso del tiempo, no era su historia la que este film iba a narrar. Ese borrado, sin embargo, era demasiado problemático para que el carácter traumático de esa experiencia no emergiera, aunque de forma tangencial e indirecta, en algunos pasajes del film.

Sobre esas emergencias volveremos más adelante, pero detengámonos ahora en la secuencia de La Moneda. La idea consistía en situar al protagonista anónimo de un acontecimiento histórico de primera magnitud en el lugar en que este hecho se había producido, pero, veintitrés años después.

\footnotetext{
${ }^{3}$ La instancia del yo narrador básico se reforzaba a lo largo de todo el relato a partir de diversas apelaciones de algunos testigos, que en sus testimonios hablaban de "tu película” o "entonces tú rodabas” y, también, por un personaje que era presentado en subtítulo como "Mi tío”.
} 
El Palacio de La Moneda, lugar de memoria ${ }^{4}$ fundamental del Chile de la dictadura, había sido el escenario de una batalla de sentidos y de apropiaciones: convertido en lugar mítico para la izquierda, la dictadura militar había tratado de borrar todas las huellas de la violencia golpista que lo habían convertido en tal. Así, inscribir a un personaje como Juan en el interior de La Moneda, hacía entrar en conflicto no sólo dos posiciones ideológicas diversas sino, sobre todo, dos memorias diferentes y, por tanto, dos formas de convocar el pasado en el presente.

La mirada perdida y desubicada de Juan daba cuenta de ese choque y del extrañamiento ante un lugar otrora familiar transformado y maquillado hoy por las estrategias de borrado histórico de la dictadura. De hecho, en el interior de la escena, Juan compartía protagonismo con un grupo de carabineros desfilando con gestualidad marcial y disciplinada. Si bien la composición del plano, en un primer momento, se abría para capturar el movimiento colectivo de éstos, cuando Juan comenzaba a adentrarse en los pasillos del Palacio, la escala de los planos se cerraba considerablemente y el movimiento de la cámara se plegaba a su trayecto.

En ese cambio de la planificación escénica podía leerse el gesto básico de la propuesta de Guzmán: escuchar y capturar aquello que del trauma violento quedaba en el espacio social heredado de la dictadura militar y de la transformación social que éste había traído consigo. La imagen documental se instalaba así en una dialéctica: entre la apertura del plano hacia el espacio general y su cierre hacia el detalle del rostro del superviviente, tratando de indagar, además, en la continuidad existente entre ambos.

\section{EL ARCHIVO Y EL SUJETO}

En su paseo por La Moneda, el ex escolta Juan se detenía ante una de las ventanas y miraba a través de ella, hacia el exterior. De acuerdo a la convención clásica del raccord entre el sujeto que mira y el objeto mirado, la película insertaba una fotografía del 11 de septiembre de 1973 que mostraba a un grupo de militares atacando el Palacio. El grano y la gama de grises de la fotografía daban cuenta del arcaísmo tecnológico del aparato con el que había sido capturada, aludiendo de ese modo al tiempo sedimentado en ella, en contraste con la imagen límpida y actual de Juan.

\footnotetext{
${ }^{4}$ La noción "el lugar de la memoria” remite a Pierre Nora, quien trata de organizar una "historia crítica de la memoria a través de sus principales puntos de cristalización, (...) comprender la administración general del pasado en el presente, mediante la disección de sus polos de fijación más significativos” (1998:32).
} 
Los tiempos de la violencia en Chile: La memoria obstinada

Al igual que en la apertura del film, el propio dispositivo de representación establecía una diferencia no sólo temporal, sino también fenomenológica, entre ambas imágenes. Frente al carácter nítido y cuidado de la imagen de Juan mirando por la ventana, la fotografía del ataque militar presentaba diversas características ligadas al pasado: era una imagen fija, con marcas evidentes del desgaste operado por el tiempo; su blanco y negro, opuesto al color de la imagen cinematográfica, remitía a un tiempo otro, arcaico tecnológicamente, tiempo del que no podía suponer más que una emergencia subjetiva, proyección de la memoria del superviviente que esa construcción escénica se proponía desencadenar.

Por una parte, el espectador era perfectamente consciente del artificio: la convención del plano-contraplano hacía posible que entendiera la relación entre las dos imágenes - entre un sujeto que mira y el objeto de su visiónpero la diferencia radical de los soportes de ambas desnaturalizaba esa relación y la hacía aparecer como un mero gesto enunciativo. Por otra parte, la vuelta al rostro de Juan emocionado por esa emergencia del pasado matizaba la naturaleza de esa relación, localizándola en el interior de la subjetividad y, de ese modo, en la fenomenología de su memoria.

Más compleja era la segunda emergencia de las imágenes del pasado que tenía lugar en esa larga secuencia. La voz en off de Guzmán explicaba: "Él es uno de esos personajes anónimos que yo filmé en esa época para hacer La batalla de Chile" y la imagen pasaba, por corte, a un plano en movimiento de la plaza de La Moneda casi vacía. Lo extraño de esa imagen es que tenía un movimiento de cámara extraño, aparentemente afuncional, que no seguía a ningún elemento interno de la imagen, como si se tratara de representar una mirada perdida. En un leve barrido final, el encuadre se centraba en un adorno del balcón desde donde Juan estaba mirando. En contraste con el vacío de las imágenes, la voz de Guzmán hablaba del insólito movimiento de masas capitaneado por Allende y de la toma popular de las calles de Santiago.

El film no tardaría en resolver esa aparente desconexión encadenando el anterior plano con uno de idéntico encuadre e igual movimiento perteneciente a La batalla de Chile, y cuya forma había sido cuidadosamente remedada, 23 años después, por la imagen que se nos acababa de mostrar. Sin embargo, si el movimiento de la imagen anterior resultaba arbitrario y afuncional, el de la imagen de La batalla de Chile seguía el ritmo y el desplazamiento de la multitud enérgica y apasionada que se manifestaba en la Plaza de La Moneda, literalizando la idea de "movimiento de masas" a la que la voz de Guzmán había aludido anteriormente.

Así, Guzmán mostraba una mirada que, en ausencia de la masa social que le había dado consistencia veinte años atrás, parecía insustancial, vacía y arbitraria. Aludía así, de un modo sutil, al vaciamiento de la participación 
popular que había hecho posible la mirada de La batalla de Chile y que, en 1996, carecía ya del sentido que había tenido en los años setenta. Lo que la arbitrariedad de ese primer movimiento de cámara hacia ver era, por tanto, la desarticulación de una realidad histórica que tornaba impertinente la mirada con que años antes había sido capturada.

Al mismo tiempo, Guzmán elaboraba la relación entre las imágenes de archivo, la presencia del superviviente y la representación del pasado y el presente. Lo hacía a través de un singular trabajo con la diferente textura de las imágenes, remarcando las tecnologías de la captación que las habían hecho posibles y su pertenencia a tiempos históricos disímiles. Estableciendo una continuidad formal entre el rostro del superviviente y las imágenes de archivo metaforizaba el desencadenamiento fenoménico de la memoria del superviviente.

Guzmán producía, así, un efecto de subjetivación sobre algunos elementos del archivo, inscribiéndolos en un proceso de reconstrucción fenoménica del pasado. Esto es, Guzmán inscribía en una economía subjetiva y fenoménica las imágenes que muchos otros documentales habían utilizado de un modo de-subjetivado a partir del paradigma del documento. De ese modo, no sólo les otorgaba un espesor simbólico muy diferente sino que las inscribía explícitamente en la lógica de la memoria.

\section{MEMORIA, SUPERVIVENCIA E IDENTIDAD}

En todo el desarrollo del film, el 11 de septiembre de 1973 marcaba el momento traumático de una pérdida. En primer lugar, de un proyecto histórico concreto pero, también, de diversas pérdidas subjetivas a las que el film aludía a través del relato de los testigos. Nelly Richard señaló que "la experiencia de la post-dictadura anuda la memoria individual y colectiva a las figuras de la ausencia, de la pérdida, de la supresión, del desaparecimiento. Figuras rodeadas todas ellas por las sombras de un duelo en suspenso" (1997:35). En ese duelo en suspenso localizaba Richard el síntoma melancólico que caracterizaba a la post-dictadura chilena, y que tenía que ver con la "pérdida de objeto" que produjo la política de desapariciones forzadas emprendida por la dictadura militar, que imposibilitó los rituales de muerte y, por tanto, el trabajo del duelo que le acompaña.

En ese contexto, el film de Guzmán aludía a esas ausencias a través de un trabajo con el tiempo del relato que trataba de explorar las diversas relaciones posibles entre el pasado y el presente. Al conectar las imágenes de 1973 con las de 1996, Guzmán utilizaba los espacios urbanos como lugares en los que el paso del tiempo había cristalizado, materializándose en sedimentos emocionales en los que el film trataba de indagar. Al mismo tiempo, 
Los tiempos de la violencia en Chile: La memoria obstinada

establecía un juego de contrastes entre los diferentes soportes de la imagen, subrayando las diferencias en la tecnología de la captación y aludiendo, de ese modo, a la diferente experiencia histórica que estaban capturando. La imagen fotográfica y el fotograma de La batalla de Chile funcionaban como depósito de ausencias, como el único resto de la presencia de los jóvenes de otro tiempo hoy desaparecidos. La fotografía, como señala Barthes (1995), indica que, por lo menos, el objeto de la representación ha estado ahí antes de desaparecer.

Hay una poderosa escena, en la cual el equipo de rodaje juntaba a un grupo de personas en una habitación y les iba mostrando fotografías e imágenes de La batalla de Chile para que reconocieran a los sujetos filmados con la esperanza de que pudieran dar alguna información sobre ellos. La respuesta más repetida era desoladora: “este está desaparecido”, pero en un caso algunos de los presentes identificaban a Carmen Vivanco una de las personas filmadas, y señalaban la posibilidad de encontrarla. El plano siguiente mostraba a la propia Carmen Vivanco sentada ante un televisor en el que se reproducía su imagen congelada de veinte años atrás. Cuando se le preguntaba si efectivamente era ella, respondía con un lacónico y estremecedor “Tengo mis dudas” que hacía explícita la crisis de una subjetividad incapaz de reconocerse en unas imágenes que, por pertenecer a un tiempo otro, era difícil relacionar con la existencia actual.

El montaje cinematográfico de Guzmán explora hábilmente ese conflicto enfrentando las imágenes del pasado y del presente: en el rostro congelado en blanco y negro que se veía en el televisor se reconocían a duras penas los rasgos del rostro envejecido de Carmen Vivanco. En el plano siguiente, Guzmán hacía más compleja esa relación: mostraba la imagen (ahora animada) de Carmen en La batalla de Chile, pero sobre ella se reflejaba - a un lado de la pantalla televisiva - la imagen (en color) de Carmen en la actualidad, mirando atentamente la película de 1973. Así, los dos soportes materiales del relato entraban en una relación dialéctica, aludiendo a la conflictiva identificación de la superviviente con su propia imagen, multiplicada y difuminada, a la vez, por el paso del tiempo y por la superficie reflectante de la pantalla.

Esa exploración de las relaciones entre las imágenes del pasado, la identidad de los supervivientes y el paso del tiempo atravesaba todo el metraje del film. En tanto documental performativo (Valenzuela, 2006:7) Chile, la memoria obstinada generaba una serie de situaciones que hacían colisionar diferentes tiempos históricos insertando prácticas y símbolos ligados al gobierno de Allende en lugares públicos del Santiago de los noventa, de donde la dictadura había borrado su memoria. Para organizar esas 
performances de la memoria, tomaba como documento y referente las imágenes de La batalla de Chile.

En primer lugar, se hacía andar rodeando un coche vacío por una calle desierta a los antiguos escoltas del coche presidencial de Allende, en una imagen que, descontextualizada, resultaba un tanto absurda, pero que se encadenaba a la misma imagen 23 años atrás, en La batalla de Chile, con Allende erguido y saludando en el interior del coche. Allende estaba acompañado por los mismos escoltas que acabábamos de ver, pero mucho más jóvenes, y rodeado por una multitud que aplaudía el paso del Presidente. Explorando los efectos del paso del tiempo sobre el cuerpo de los escoltas, se intercalaban imágenes de estos viendo en la televisión La batalla de Chile y tratando de reconocerse unos a otros en la película. En segundo lugar, en el centro de Santiago, una banda de música interpretaba Venceremos, himno programático de la Unidad Popular que no se había escuchado públicamente desde 1973. La banda recorría las calles más transitadas de la capital ante la mirada atónita de los transeúntes: la cámara trataba de capturar entonces el gesto sorprendido de sus rostros conmocionados al escuchar un himno inusualmente cargado de memoria.

\section{LA CONTINUIDAD DE LA VIOLENCIA}

En una de las últimas y más estremecedoras secuencias de la película se daban cita la mayoría de las operaciones que he venido describiendo. Esta secuencia se desarrollaba así: en el testimonio de un médico amigo de Guzmán se nombraba el Estadio Nacional, donde el propio Guzmán fue confinado. Aparecían, entonces, imágenes actuales del interior del Estadio (pasillos donde, sabemos, fueron hacinados los detenidos) totalmente vacío, con un movimiento de cámara circular de $360^{\circ}$, mientras la voz de Guzmán señalaba: "Después de 23 años vuelvo al Estadio con un amigo". Tras varios planos cortos que mostraban pasillos y rejas del interior del Estadio, la imagen volvía a centrarse en el testigo, que aludiendo al propio Guzmán señalaba: "Un día fui al Estadio y te encontré a ti”.

A esas palabras, que aludían por primera y única vez al carácter de superviviente del Director, ${ }^{5}$ seguían unas imágenes actuales del campo de juego, totalmente vacío, que contrastaban con la saturación interna del plano que venía después: una imagen de archivo de septiembre de 1973 con el mismo encuadre y desde el mismo punto de vista, con un militar en primer

\footnotetext{
${ }^{5}$ El impresionante relato de sus catorce días en el camarín seis del Estadio Nacional puede
} hallarse en Patricio Guzmán. “Catorce días en el camarín seis del Estadio Nacional”, 1977. 
plano. Al fondo, numerosas personas hacinadas en las gradas, sufriendo la represión inmediatamente posterior al Golpe. Establecida ya esa relación recurrente en la película entre dos planos idénticos en sus límites externos pero radicalmente diferentes en su interior, la voz de Guzmán, didácticamente, explicaba: "En 1973 miles de personas pasaron por aquí, el Estadio fue la primera gran escuela del terror que se nos venía encima”.

La voz se callaba, entonces, y aparecían diversos planos actuales del interior del Estadio, repleto de carabineros con un uniforme idéntico al de 1973. La cámara recorría los vestuarios de los carabineros, donde comenzaban a armarse y a tomar los escudos que habrían de servirles de protección para una acción represiva: daba la impresión, entonces, que el film recurría a una reconstrucción escénica, ficcional, de la represión policial del 73. Esa impresión se consolidaba con la aparición de tres fotografías de septiembre del 73 que mostraban a los carabineros en el Estadio con detenidos que llevaban las manos en la nuca. De nuevo, mediante un encadenado, volvían a aparecer los carabineros, en la actualidad, preparándose para la batalla en el interior del Estadio con escudos, chalecos antibala, cascos, armas de fuego, lo que se volvía a alternar — produciendo un clímax visual muy potente- con un plano de archivo de los militares en 1973, protegidos de forma muy similar.

La ambigüedad sobre el estatuto de esas imágenes desaparecía cuando se retomaba plano anterior de los carabineros armados en 1996 y la cámara los seguía en su entrada al campo de juego, con las gradas repletas de aficionados enfebrecidos en las que se desarrollaban escenas de violencia más o menos controladas: insultos, cánticos, bengalas, humo; esto es, escenas propias de un acontecimiento deportivo de gran rivalidad. A su lado, los carabineros se mostraban orgullosamente expectantes, dispuestos a intervenir en cualquier momento en ese festejo deportivo que cobraba la apariencia, por momentos, de una guerra campal.

Mediante ese montaje abiertamente conceptual, en el Chile aparentemente pacificado de 1996 el film aludía a la pervivencia de la represión, de su iconografía y de los valores morales sobre los que se asentaba. De ese modo, el film aludía al desplazamiento de las formas de la violencia que la transformación neoliberal de Chile había producido. Si las imágenes de los carabineros, su actitud desafiante y violenta se representaban en perfecta continuidad con aquellas cercanas al golpe del 73, las de los aficionados enfebrecidos por el fútbol contrastaban radicalmente con aquellas otras representaciones de la multitud que La batalla de Chile había presentado. Una idea esencial podía desligarse de ese montaje contrastivo: entre las multitudinarias manifestaciones políticas que habían hecho de la toma de las calles su método privilegiado de expresión y la violencia deportiva de los años noventa 
mediaba un proceso de vaciado y expropiación de la expresividad popular y de sus formas de participación ciudadana.

\section{CONCLUSIONES: LAS CONEXIONES SUBTERRÁNEAS Y LAS TRAZAS DEL NARRADOR}

Mediante procedimientos como entrevista a supervivientes, montaje conceptual, subjetivación de elementos del archivo La memoria obstinada visibilizaba las conexiones subterráneas entre la violencia que siguió al Golpe y el espacio social de la Transición, insistiendo en el carácter conflictivo de las representaciones de la violencia en los años noventa. El carácter performativo y profundamente autorreflexivo del documental permitía, además, realizar un impresionante trabajo con las imágenes de archivo, inscribiéndolas en nuevas cadenas de sentido capaces de apoyar las rememoraciones subjetivas de los supervivientes y de explorar los conflictos latentes en ellos entre su posición actual y las imágenes de su propio pasado.

El relato de La memoria obstinada está sostenido sobre la alusión frágil y lateral al carácter de superviviente - de aquel que se proponía como el garante del discurso- y que, de esa forma, rehuía las formas institucionallizadas que la Transición iba a habilitar para la representación de la violencia a través de la palabra del testigo. Sin embargo, las alusiones que a lo largo de todo el film Guzmán dejaba caer en el discurso, permiten pensar que aquel acontecimiento traumático sobre el que había testimoniado en Catorce días (1977), aunque excluido como tal de la representación, tenía sin embargo un carácter nuclear en ella.

En los años posteriores a la producción de La memoria obstinada las políticas oficiales de memoria consiguieron llevar a su seno a muchas de las enunciaciones testimoniales, inscribiéndolas en su lógica consensual y vaciándolas del valor combativo que habían tenido antaño (Peris Blanes, 2008:17). Sin embargo, la apuesta de Guzmán se situaba a una gran distancia de esas nuevas texturas de la memoria, fundamentalmente afectivas e individualizadas, e inscribía las huellas de su memoria traumática en un discurso que excedía con mucho lo personal y que, como se ha mostrado aquí, exploraba la conexión política, histórica y vivencial entre dos tiempos históricos que las políticas oficiales de memoria estaban tratando de desconectar: el de la brutal represión que siguió al golpe de 1973 y el del Chile neoliberal, anestesiado y traumatizado, que la nueva democracia había heredado de la dictadura militar. 
Los tiempos de la violencia en Chile: La memoria obstinada

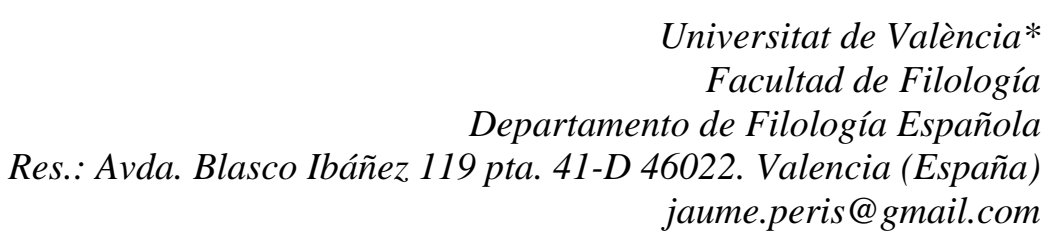

\section{BIBLIOGRAFÍA}

BAUDRY, Patrick. La place des morts. Enjeux et rites. Paris: Armand Collin, 1999.

BARTHES, Roland. La cámara lúcida: nota sobre la fotografía. Barcelona: Paidós, 1995.

GUZMÁN, Patricio. Chile, La memoria obstinada. ARTE / Les films d'ici, 1997.

“La memoria obstinada. Proyecto / Guión imaginario”, en Viridiana 17 (1997).

"Catorce días en el camarín seis del Estadio Nacional”, en El cine contra el fascismo (Guzmán, Patricio; Sempere, Pedro, eds). València: Fernando Torres (1977):209-250.

------- La batalla de Chile: la lucha de un pueblo sin armas. Equipo Tercer Año: 1975.

KLUBOCK, Thomas Miller. "History and Memory in Neoliberal Chile: Patricio Guzman's Obstinate Memory and The Battle of Chile", en Radical History Review 85 (2003):272-281.

LANZMANN, Claude. "The obscenity of understanding", en Trauma. Explorations in memory (Cathy Caruth). Baltimore: John Hopkins (1995):201-220.

------- “De l'Holocauste a Holocauste ou comment s'en debarraser”, en Les Temps Modernes 395 (1979):1897-1909.

MILLÁN, Francisco Javier. "La memoria agitada" en Cine y represión en Chile y Argentina. Huelva: Fundación Cultural de Cine Iberoamericano de Huelva-Librería Ocho y Medio, 2001.

NORA, Pierre. "La aventura de Les lieux de mémoire”, en Ayer 32 (1998):1734.

PERIS BLANES, Jaume. Historia del testimonio chileno. De las estrategias de denuncia a las políticas de memoria. València: Anejos de Quaderns de Filologia, 2008.

------- La imposible voz. Memoria y representación de los campos de concentración en Chile: la posición del testigo. Santiago: Cuarto Propio, 2005. 
Jaume Peris Blanes

RICHARD, Nelly. Residuos y metáforas. (Ensayos de crítica cultural sobre el Chile de la Transición). Santiago: Cuarto Propio, 1998.

"Con motivo del 11 de septiembre. Notas sobre La memoria obstinada (1996) de Patricio Guzmán”, en Revista de Crítica Cultural 15. Santiago: (1997):54-61.

VALENZUELA, Valeria. "Yo te digo que el mundo es así: giro preformativo en el documental chileno contemporáneo". Doc. on-line, en Revista digital de cinema documentario 1 (2006):6-22. 